Sheridan College

SOURCE: Sheridan Institutional Repository

$11-2-2020$

\title{
Domestic Violence in Immigrant Communities: Breaking the Cycle
}

\author{
Ferzana Chaze \\ Sheridan College, ferzana.chaze@sheridancollege.ca \\ Bethany Osborne \\ Sheridan College, bethany.osborne@sheridancollege.ca \\ Archana Medhekar \\ Purnima George \\ Ryerson University
}

Follow this and additional works at: https://source.sheridancollege.ca/conferences_dvic_btc

Part of the Domestic and Intimate Partner Violence Commons, Social Work Commons, and the Women's Studies Commons

\section{SOURCE Citation}

Chaze, Ferzana; Osborne, Bethany; Medhekar, Archana; and George, Purnima, "Domestic Violence in Immigrant Communities: Breaking the Cycle" (2020). Dissemination Event. 1.

https://source.sheridancollege.ca/conferences_dvic_btc/1

\section{(c)}

This work is licensed under a Creative Commons Attribution-Noncommercial-No Derivative Works 4.0 License. This Webinar is brought to you for free and open access by the Domestic Violence in Immigrant Communities: Breaking the Cycle at SOURCE: Sheridan Institutional Repository. It has been accepted for inclusion in Dissemination Event by an authorized administrator of SOURCE: Sheridan Institutional Repository. For more information, please contact source@sheridancollege.ca. 


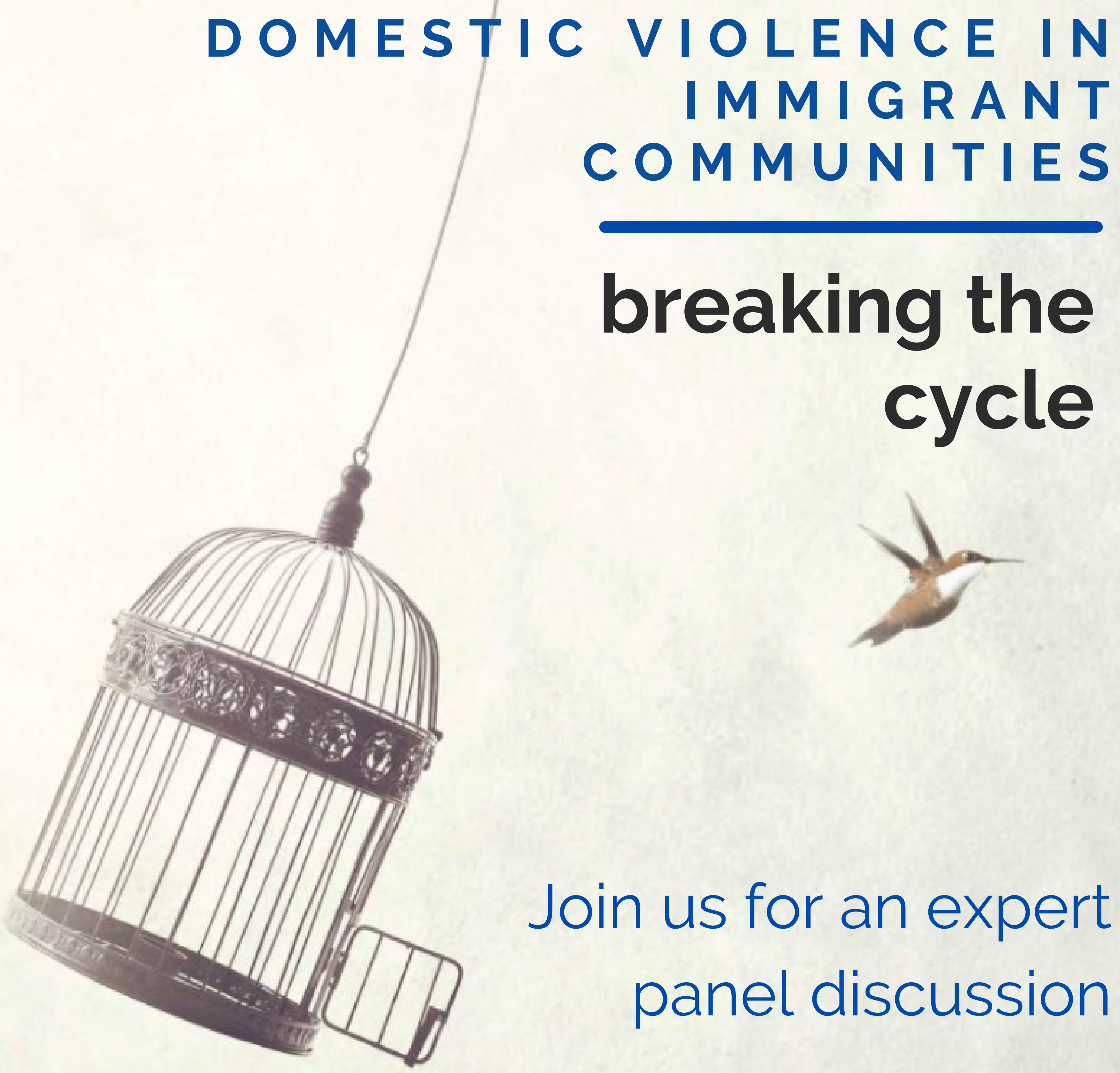

with Justice Gerri Wong from the Family Court; Lianne Kendall, Sheridan's Sexual Violence Response Specialist; Antionette Clarke from Peel Family Mediation; and Professor Nick Bala from Queen's University as we engage in conversations about Domestic Violence and how to work more effectively to support vulnerable women and their families.

\section{DATE | MONDAY NOVEMBER 2, 2020 TIME |1-2:30 PM}

This event was made possible by: Sheridan $\mid$ Greative 